\title{
Cytogenetic Study on Mutagenic Effect of Cola Containing Soft Drinks on Vicia faba
}

\author{
Aida A. Elsharief ${ }^{1,2^{*}}$ \\ ${ }^{1}$ The University College in Al-Khafji, Khafji, University of Hafr Al Batin, Saudi Arabia \\ ${ }^{2}$ College of Applied Sciences, University of Bahri, Khartoum, Sudan \\ *Corresponding author
}

\section{A B S T R A C T}

\section{Keywords}

Vicia faba, Cola soft drinks, Mitosis, Chromosomal aberrations

Article Info

Accepted:

12 March 2021

Available Online:

10 April 2021
The potential genotoxicity of cola- containing soft drink was investigated by Vicia faba assay. Root tips were treated with different concentrations of the cola- containing soft drink $(100 \%$ and $50 \%)$ at 24 hours exposure. The concentration exposure affected the mitotic division in root tip cells and produced various chromosomal aberrations. The abnormalities scored were, bridges, fragments, lobulated nuclei, sticky metaphase and sticky anaphase. Exposure to soft drinks inhibited the cell cycle in a concentration dependent manner.

\section{Introduction}

The rapid change in life styles has led to the extensive use of processed food products that contain harmful chemicals used either for preservation, giving flavor, color, taste and or smell. This type of dietary led to spread of many diseases such as kidney failure, cancer and Alzheimer's. These harmful effects raise the attention of scientists to study their effects on cells.

Cola-containing drinks are among the most common drinks in the world which become part of human consumption. They have replaced natural fruit juices and become part of daily dietary habits. Long-term consumption of caffeinated soft drinks appears to have bone catabolic effects in youth. The consumption of sucrose-sweetened soft drinks (SSSDs) has been associated with obesity, the metabolic syndrome, and cardiovascular disorders in observational and short-term intervention studies (Maersk et al., 2012).

Caffeine is an added ingredient in approximately $70 \%$ of soft drinks consumed in the United States. The soft drink manufacturers' justification to regulatory agencies and the public for adding caffeine to soft drinks is that caffeine is a flavoring agent (Griffiths and Vernotica, 2000). 
Soft drinks are non-alcoholic water-based flavored drinks that are optionally sweetened, acidulated, carbonated and which may contain fruit, fruit juice and/or salts; their flavor may derive from vegetable extracts or other aromatic substances. Aromatic substances are added to soft drinks to give a pleasant taste and better stability to the taste. These could be natural aromatic substances like caffeine obtainable from a variety of leaves, seeds and fruits (Mathur et al., 2003).

Pandey et al., (2014) found significant decrease in mitotic index in Allium cepa due to treatment of five types of food preservatives commonly used in the United States and India. Food preservatives also caused changes in the frequency of cell stages and also their treatment induced a wide range of mitotic abnormalities. Several chromosomal abnormalities at metaphase and anaphase recorded were bridges, chromosomal break, lobulated nucleus, laggard multipolarity, stickiness and C-mitosis.

Hannah et al., (2010) demonstrated that mitotic index of Allium cepa root tips treated with Coke and Pepsi showed high significant reduction in mitotic index. Cola drinks induced various chromosomal abnormalities such as clump, fragment, laggard, bridge, ring, break, tri and multipolar anaphase, Cmetaphase, disturbed and abortive anaphase, and higher frequencies of aberrations were found during longer exposure.

George and George (2017) reported number of chromosomal abnormalities in Allium cepa due to treatment with cola soft drink. The most common aberrations are chromosome bridges, breaks, condensation, spindle abnormalities, lagging and binucleated cells.

Exposure of cells to DNA damaging agents induces a pause or arrest in their cell cycle progression at distinct points, called checkpoints, to allow time for DNA repair. The G1/S checkpoint delays entry into $S$ phase and the G2/M checkpoint temporarily prevents entry into mitosis. Both checkpoints allow time for DNA repair and prevent replication of damaged DNA and propagation of genetic abnormalities. However, if the DNA damage is too extensive, the injured cells will undergo cell death or apoptosis. Both apoptosis and cell cycle arrest are normally mediated by the tumor suppressor protein p53 (Bode and Dong, 2007).

Caffeine has been reported to affect cell cycle function, induce programmed cell death or apoptosis and perturb key regulatory proteins, including the tumor suppressor protein, p53 (He Z et al., 2003), (Ito K et al., 2003).

Vicia faba is one of the cytogenetically best characterized plants. Its six chromosome pairs contain as much as 1C approximately $13 \mathrm{pg}$ (picogram) of DNA, which corresponds approximately to $13000 \mathrm{Mbp}$ (mega base pair). The first, very large chromosome (about $18 \mu \mathrm{m}$ length) is metacentric, with one satellite. There are five similar (approx. 7-9 $\mu \mathrm{m}$ length) acrocentric chromosomes. The metacentric chromosome I of $V$. faba probably originated from a remote fusion of two telocentric chromosomes. Many cytogenetic phenomena were observed for the first time by studying $V$. faba, for instance, nucleolus formation at the secondary constrictions during telophase, or the existence of an upper tolerance limit for chromosome arm length (Schubert and Oud, 1997).

The objective of this work is to study the effect of cola containing soft drinks on mitotic division in Vicia faba.

\section{Materials and Methods}

Vicia faba L. major $(2 \mathrm{n}=12)$ seeds were used as test system. Seeds were set for germination 
between cotton layers to obtain root tips. The root tips were excised and treated with different concentrations of cola- containing soft drink $(100 \%$ and $50 \%$ respectively) against a control of root tips immersed in distilled water. After 24 hours the treated root tips and control were washed in distilled water and fixed with carnoy's solution for 24 hours. Root tips were washed with distilled water and kept in $70 \%$ ethyle alcohol. Mitotic preparation was made using squash method technique (Ahloowalia, 1965). Double stains aceto- carmine and leuco-basic fuchsin were used.

Chromosomal aberrations were determined using light microscope.

\section{Results and Discussion}

V. faba root tips immersed in 50\% colacontaining soft drink for 24 hours showed a non-significant decrease in mitotic abnormalities, although the number of cells in anaphase and metaphase showed some decrease which could be as a result of delay in the cell cycle, G1/S checkpoint delays entry into $S$ phase and the G2/M checkpoint temporarily prevents entry into mitosis which may be caused by treatment with colacontaining soft drink, This result agree with the result obtained by (Truta et al., 2009). There was a decrease in the number of cells in telophase in root tips immersed in $100 \%$ concentration, which may reflectmore delay in the cell cycle which may be due to blocking in the $\mathrm{G} 2$ phase of the cell cycle preventing the cell from entering mitosis. Large number of chromosomal aberrations was observed. Most aberrations were observed in metaphase and anaphase. Chromosomal aberrations include; stickiness of chromosomes which may be resulted from increased chromosomal contraction and condensation or might from the depolymerization of DNA and partial dissolution of nucleoproteins. Chromosome stickiness reflects toxic effects, usually of an irreversible type and probably leading to cell death (Celik and Aslanturk, 2007).

Lagging chromosomes found which resulted due to failure of chromosomes to get attached to the spindle fibers and move to either pole, according to (Torkoglu, 2007). Chromosome bridges recorded may result due to failure of separation of the two chromatids in one or more pairs of chromosomes, as found by (Dusman et al., 2013). This type of anomaly was also observed in the mitosis of Allium cepa after treatments with food additives(Gomurgen,2005).

Soft drinks containing cola brought about mito- inhibitory effect and hence are genotoxic chemicals induce chromosomal aberrations reflected in the products of cell division and leads to formation of genetically defected cells.

Table.1 Cytogenetic analysis of Vicia faba root tips exposed to different concentrations of colacontaining soft drink

\begin{tabular}{|c|c|c|c|c|c|c|c|}
\hline $\begin{array}{c}\text { Cola } \\
\text { drink } \\
\text { conc. }\end{array}$ & $\begin{array}{c}\text { Total } \\
\text { number of } \\
\text { aberrations }\end{array}$ & $\begin{array}{c}\text { Mitotic } \\
\text { abnormalities } \\
\text { mean (\%) }\end{array}$ & $\begin{array}{c}\text { Total } \\
\text { number } \\
\text { of cells in } \\
\text { prophase }\end{array}$ & $\begin{array}{c}\text { Total } \\
\text { number of } \\
\text { cells } \\
\text { inmetaphase }\end{array}$ & $\begin{array}{c}\text { Total } \\
\text { number } \\
\text { of cells in } \\
\text { anaphase }\end{array}$ & $\begin{array}{c}\text { Total } \\
\text { number } \\
\text { of cells in } \\
\text { telophase }\end{array}$ & $\begin{array}{c}\text { Total } \\
\text { number } \\
\text { of cells }\end{array}$ \\
\hline $\mathbf{5 0 \%}$ & 5 & $5.10 \%$ & 46 & 6 & 6 & 40 & 98 \\
\hline $\mathbf{1 0 0 \%}$ & 14 & $14.14 \%$ & 52 & 5 & 7 & 35 & 99 \\
\hline Control & 0 & $0.0 \%$ & 30 & 10 & 12 & 53 & 105 \\
\hline
\end{tabular}


Fig.1 Root tips of Vicia faba showing various mitotic chromosomal aberrations
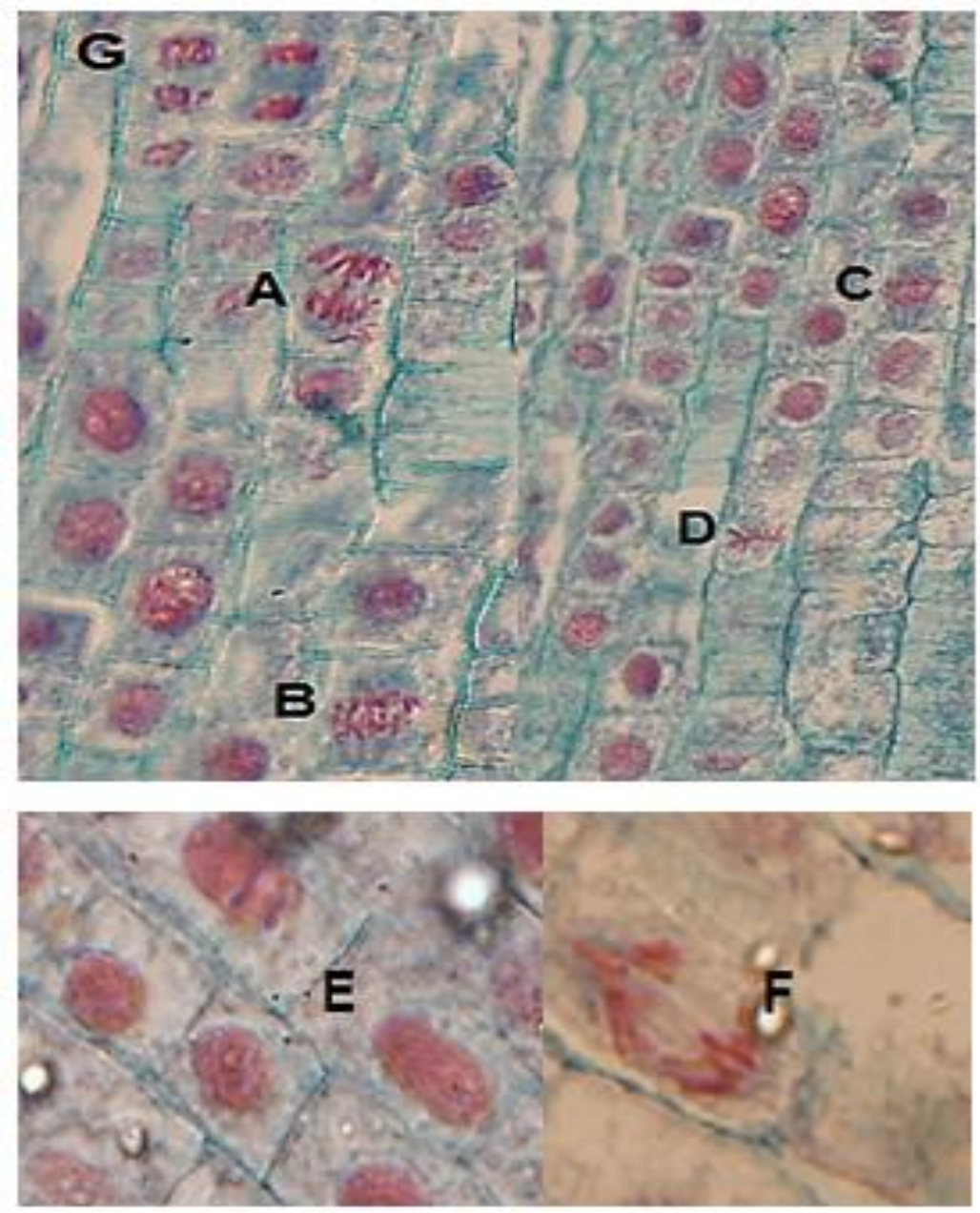

A: Laggared anaphase with bridge and breaks,

B: Abnormal anaphase with bridges

C: Abnormal anaphase,

D: Sticky metaphase

E: Lobulated nuclei,

F: Sticky anaphase with breaks

G: Sticky anaphase

\section{References}

Ahloowalia, B. S. (1965). A root tip squash technique for screening chromosome number in Lolium. Euphytica, 14(2), $170-172$.

Bode, A. M., \& Dong, Z. (2007). The enigmatic effects of caffeine in cell cycle and cancer. Cancer Letters, 247(1-2), 26-39. https://doi.org/10.1016/j.canlet.2006.0 3.032

Celik T. A., Aslanturk O. S. Cytotoxic and genotoxic effects of Lavandula stoechas aqueous extracts. Biologia, 2007; 62: 292-296

Dusman E., Perti A., Soares, L. C. and Vicentini, V. E (2013). Cytotoxicity and Mutagenicity of cola and flavored soft drinks in bone marrow cells of rodents. Food SciTechnolVol 33 (1).

George, M., \& George, A. (2017). Genotoxicity of Caffeinated Soft Drinks on Meristematic Root Cells of Allium

Cepa.22032-22038. 
https://doi.org/10.15680/IJIRSET.2017 .0611037

Gomurgen A. N. Cytological effect of the potassium metabisulphite and potassium nitrate food preservative on root tips of Allium cepa L. Cytologia, 2005; 70: 119-128.

Griffiths, R. R., \& Vernotica, E. M. (2000). Is caffeine a flavoring agent in cola soft drinks? Archives of Family Medicine. https://doi.org/10.1001/archfami.9.8.72 7

Hannah, C., Priya, E. J. S., \& Mammen, A. (2010). Duration dependent mutagenic study of cola drinks on Allium cepa L. Biosciences Biotechnology Research Asia, 7(2), 807-812.

He Z, Ma WY, Hashimoto T, Bode AM, Yang CS, Dong Z. Induction of apoptosis by caffeine is mediated by the p53, bax, and caspase 3 pathways. Cancer Res 2003;63:4396-4401.

Ito K, Nakazato T, Miyakawa Y, Yamato K, Ikeda Y, Kizaki M. Caffeine induces $\mathrm{g} 2 / \mathrm{m}$ arrest and apoptosis via a novel p53-dependent pathway in nb4 promyelocytic leukemia cells. J Cell Physiol 2003;196:276-283. [PubMed: 12811820

Maersk, M., Belza, A., Stødkilde-Jørgensen, H., Ringgaard, S., Chabanova, E., Thomsen, H., Pedersen, S. B., Astrup, A., \& Richelsen, B. (2012). Sucrose- sweetened beverages increase fat storage in the liver, muscle, and visceral fat depot: A 6-mo randomized intervention study. American Journal of Clinical Nutrition.

Mathur, H. B., Johnson, S. and Kumar, A.(2003) Analysis of Pesticides Residues in Soft Drinks. Centre of Science and Environment. CSE Report Delhi, India.

Pandey, H., Kumar, V., \& Roy, B. K. (2014). Assessment of genotoxicity of some common food preservatives using Allium cepa L. as a test plant. Toxicology Reports, 1, 300-308.

Schubert, I., and Oud, J. L. (1997).There is an upper limit of chromosome size for normal development of an organism. Cell 88, 515-520.

Truta, E., Surdu, S., Olteanu Z. (2009) Cytogenetic effect induced by caffeine in Cannabis sativus (hemp) root meristems. plant fungal and habitat diversity investigation and conservation: Proceeding of Palkan Botonical Congress. Sofia 20 -26.

Turkoglu S.(2007). Genotoxicity of five food preservatives tested on root tips of Allium cepa L. Mutation Research/ Genetic Toxicology and Environmental Mutagenesis,; 626: 414.

\section{How to cite this article:}

Aida A. Elsharief. 2021. Cytogenetic Study on Mutagenic Effect of Cola Containing Soft Drinks on Vicia faba. Int.J.Curr.Microbiol.App.Sci. 10(04): 263-267. doi: https://doi.org/10.20546/ijcmas.2021.1004.027 